\title{
Western Education and Its Effects on Yoruba Social Institutions: Yoruba Religious Education as Case Study
}

\author{
Abolarin Omolade Arinola \\ Department of Yoruba \\ School of Languages \\ Federal College of Education, Kontagora-Nigeria
}

\section{Doi:10.5901/ajis.2013.v2n6p147}

\begin{abstract}
Religion denotes man's experience,awareness, attitude, recognition, conception and understanding of spiritual beings and his relationshipor interaction with them. This paper examines the effect of Western Education on Yoruba religious beliefs. Our views is that Yoruba religious belief are dying out, with very few people willing to take their place. Efforts must be made to retain the good values that Yoruba religion and culture believe in.
\end{abstract}

\section{Introduction}

Education it self is complex. The metaphor, education is used differently and this leads scholars to hold or have different yard tick for its measurement. It remain open to an endless search for values attached to it (Ornstein \& Levine, 2006). Again, education is mystified by some and misunderstood by many. However, before the introduction of western formal education in Nigeria, there existed the type of education which was in favour of the Nigeria cultural life style. To this end, Fafunwa (2004) stated that Nigeria, like other nations of world use education to train thier children, right from childhood to adulthood. This was the practice before the advent of European Missionary education. This training goes around families; it is done by parents, brothers and grant parents to understand, appreciate and promote the cultural heritage of the community at large.

This is to say that education is a tool for disseminating ot transmitting societal values knowledge and cultural heritage from one generation to another. In the same vein, the Federal Government of Nigeria (2004) posits that:

Education is an instrument for national development: to this end, the formulation of ideas, thier integration for national development and the interaction of persons and ideas are all aspects of education. Education fosters the worth and development of the individual for his sake and for the sake of the general development of the society (pp. 6 - 7)

\section{Religion and its Function in Human Society}

Religion perse is not easy to define. Neither is there any definition that is generally accepted among religious scholars. The study of religion involves many religious traditions and perspectives like sociological, psychological, historical, theological, phenomenological, and comparative approaches. These approaches further pose the problem of providing a wholistic view of what constitutes religion. The above is couple with the science of religion in which empirical and scientific methods are used in the study of religion. Modern scholars are calling for explicit theories, valid definitions, explanations, and understanding of religion to cement its scientific nature. 
However, religion denotes man's experience awareness, attitudes recognition, conception, and understanding of the existence of the supernatural or the multipliciity of spiritual beings and his relationship or interaction with them. It has to do with not only the beliefs but also the practice of soceity based on divine revelation and thier corresponding response to the Holy. It is the idea of the sacred or holy that usually colours what they believe, people's lifestyles, ethical systems, worship, and veneration. The relationship between man and God is further reflected in man's relationship to his fellows in human society.

Religion is therefore very important in human society. It provides meaning for life, answers the most fundamental questions regarding life, death and life hereafter. It confers sacred values on peoples, social laws and institutions, a cohesive and integrative element in society and, above all, consoles men in crisis situtations.

\section{Yoruba Concept of God}

The Yoruba call God Olodumare. Apart from this principal name, there are two others, Olorun and Olofin Orun.

Oludumare: The name is made up of parts: Olo, Odu and Mare. Olo meaning owner or Lord of; Odu meaning heading, chapter or the chief heading or principal heading. Odu also means fullness or very large. This is because Odu is used of a full cell in the Ayo board (Akan Oware). When these two aspects are combined Olodu is derived which would then mean: "One who owns power and authority, the supreme head who has the fullness of things". Mare can mean "do not go" or "that which is permanent". Are is a symbol of uniqueness and refers to the original crown worn by the first Yoruba king. Thus Olodumare means "a Being who is Lord and Supreme, and who has the added quality of being stable, reliable, dependable and of unique majesty".

Olorun: This is the everyday use of the divine name and it is made up of the prefix Ol from Oni) which means owner and Orun meaning heaven. Olurun therefore means owner of heaven or the Lord of heaven. This signifies the transcendent reality of God as well as the universality of his sovereignity.

Olofin Orun: This name is used in liturgies as alternative to Olodumare. Olofin gives the idea of someone who occupies a palace, a King. Thus this divine name signifies the high office of Olodumare as the Supreme Ruler who is in heaven.

All the above names of God are descriptive of this character and emphatic of the fact that he is a reality with whom one can enter into communion and communication and not an anstract concept.

\section{Religion and Morality}

It is the contention of some moral theorists that morality has no relatioship with religion.

With particular reference to West African traditional Religion what the moral theorists are saying is that the moral and social orders are not the ordinances of God. They are on the man-toman level of morality (i.e. vertical). That is to say that the social sanctions are human institutions; they were given by the ancestors. A taboo is observed because the ancestors have ordained it or because it is a custom. This would also make the Traditional Religion belong to "shame culture", by which people refrain from anti-social behaviour in consequence of public opinion.

However, in West African Traditional Religion morality is the fruit of religion. This means that in the traditional context there is no such distinction between morality and traditional context there is close relationship between religion and the moral life. The social and moral ordinances are the injunctions of God, who had himself instituted them. 
The relationship between religion and morality in the traditional setting is further seen in the concept of the justice of God - justice with particular reference to the social and moral orders. The Yoruba word Otiti which may be translated Righteousness has to do with God's dealings with man, man's relation to God and to his fellow human being. Otito is the plumb-line by which man measures his moral bearing in relation to God and his fellow men and the social order in general. The watch-dog of this moral principle is a retributive principle known as the rewarder-avenger.

The 'wrath of God' is one element of God's justice of which Africans are ever conscious. This wrath takes on concrete manifestation in the affliction connected with thunder. The Neolithic axes found in shrines as cult objects represent the instrument of affliction. The axes belong to God himself and they are thrown at the children to disobedience. Nyame-Akumo (God's axe) is generally to be found in the shrines of Onyame among the Akans. In Nigeria there is always the divine Minister of justice who is the Solar and Thunder divinity and variously called Jakuta (Sango), Oranfe, Sokogba and Amadi-Oha. Thus the world belongs to God; the social and moral orders are according to his ordinances, far above all divisions and races.

The divinities also provide sanctions for moral and ritual behaviour. There are certain actions which offend the divinities and when these are committed, they involve their wrath. For instance, offending the god in its own area of authority by violating taboos connected with its worship brings retribution in the form of misfortune, disease and even death.

Similarly the ancestors as guardians of tribal traditions and customs and custodians of law, morality and customs of the family and tribe (for and on behalf of God) do punish those who disobey the norms of the society with misfortune and reward the law abiding with prosperity.

Thus in West African Traditional Religion the basis of moral behaviour is religion. The moral and ethical sanction derive largely from God, who upholds the moral law acts sometimes through the divinities and the ancestors.

\section{Religion and Social Behaviour}

Traditional beliefs to a large extent influence social and moral behaviour. The extent to which religious beliefs exert strong impact on social and moral behaviour is accounted for by the sociological and religious composition of man.

Sociologically speaking, man as a social animal is a gregarious being. Living in physical and moral isolation is alien to his nature. He seeks company with other men and fellowship with others because as a social being he does not want a solitary life. Human beings everywhere want wholeness, solidarity and tenacity of purpose. They also want deliverance from the world and its threat. All this induce rules and regulations for right conduct which influence his social and moral behaviour.

Man is also an integrated whole. His physical and spiritual elements are one and indivisible. Man's spiritual element (the soul) links him with God and makes him aware of his creator. Thus man is aware of God and is dependent upon him. The divine part in him urges him to seek after God and at the same time to maintain fellowship with his fellow men. Thus the sociological drive in man to seek the company of others derive from his religious nature.

The traditional belief that God created the world and man means that society came into being by God's ordinance. Thus every institution is religious oriented. Therefore all the important occasions in life such as birth, puberty, marriage and death have religious ceremonies connected with them. Similarly other important events like cultivation, trading and the founding of villages and towns are all done after divination in order to consult the divine. The oracle is consulted to know exactly what to offer to the divine being in order to obtain his sanction and permission. Thus Africans believe that religious sanction must be obtained before undertaking all of the above and every act of life. 
Apart from the divine element in man which draws him into the company of his fellow men, there is the element of covenant in man. Indeed the whole of the person-to-person and divinity-toperson relations have their basis largely in covenants. The covenant between two persons is usually a parity agreement because it is reciprocal, that is both parties bind themselves to each other by bilateral obligations in order to achieve a particular objective. This brings cohesion and harmony into the society when both parties are faithful to the terms of the covenant. The divine covenant is of a unilateral kind. In return for protection and security man entrusts his life to the divine. This is the type of covenant a person automatically enters on becoming the worshipper of a divinity. The observance of things which please the divinity promote good relations between the divinity and his devotee. The worshipper must keep to the terms of the covenant and let them worshipper must keep to the terms of the covenant and let them govern his social and moral behaviour forever after. Thus the covenant idea gives meaning to peace, order and harmony thereby giving cohesion to society.

West Africans strongly believe that moral values are not invented by human beings, but are the offspring of religion. This is so because God has put his law into man and it is this which is referred to as Conscience. Thus man is expected to use his conscience to behave in a morally good way in order to avoid the 'wrath' of God. As an impartial judge God's judgment is sure and inescapable. Some of the divinities represent the 'wrath' of God and for this also man comports himself socially and morally in order to be on the safer side.

\section{Effect of Western Education on Yoruba Religious Beliefs}

The main features of West African Traditional Religious beliefs and prtactices with regard to God and the supersensible world have been described in these beliefs and practiced as observed have been influenced to a certain degree by external forces. The advent of Western civilization has changed the simplicities of traditional life and though. Foreing religions (especially Islam and Christianity) have also had thier toll. In view of all these changes the natural question is: what future has the traditional religion? This is evidently not a simple question to answer. Opinion is divided on the issue. A school of thought maintain that with all these rapid changes the traditional religion has not only become outmoded but will die a natural death with time. They are the prophets of doom. Another school of thought, apparently aware of the threats posed to the very existence of the traditional religion, are hopeful that the faith of our ancestors will stand the test of time, though in a modified form, while at the same time retaining some of its originality. It is vital to examine the arguments on either side.

Those who hold the view that in consequence of the impact of external forces the traditional religion has become outmoded, and irrevant, and therefore cannot survive in the near future, first of all point to the devastating effect of Western civilization. The advent of Western civilization has brought in its wake urbanization and industrialization which have disturbed and transformed the relative peaceful and stable order of the rural areas. Many people especially the youth have drifted to the urban centres in search of job opportunities. In the process, the youth no longer enjoy the security of the village life. Traditional rites like puberty which ensures the smooth transition from childhood into adulthood by giving the youth a sense of moral direction are no longer performed. Since such people are no longer under the watchful care of thier families they become anonymous entities, completely lost in the rat race for mere survival. Traditional values are discarded in a complex money economy. Traditional sanctions and taboos are no longer treasured and a new way of life begins which leads to a new kinds of morality. Respect for the elders is now decline and chastity before and during marrige is becoming a thing of the past. Traditional hospitality and generosity which make each his brother's keeper is replaced by a new morality which stresses 
selfishness as a virtu, "Each man for himself and God for us all". Thus all that is good in traditional morality is lost in the name of civilization.

Closely connected with rapid urbanization and industrialization is gormal education. Western and Eastern types of education have drastically influenced the life and thought of the average West African in consequence of the exposure to foreign cultures, which are in some respects higher and more sophisticated than traditional values. There are educated elites, more enlightened, more scientific in thier ideas and therefore more pragmatic in thier approach to complex issues affecting thier material and spiritual well being. Traditional explanations for certain happenings in human life are ragarded as superstitious. The killing of twins and the punishment of thier mother is found to be unnatural; infant mortality is no longer blamed on abiku spirits and scientific agriculture emphasising good drainage patterns, pest and flood control and manuring, have weakened the belief in evil forces like withchraft, magic and sorcery, which were formerly blamed for all sorts of misfortunes in the society. The result that the traditional way of life is considered as primitive and crude and the traditional religion as a religion of the uncivilized and nobody wants to be associated with it, at least openly. If public records are anything to go by then eventual disappearance of the traditional religion is certain. This is because on employment forms and hospital cards where the religion of the individual is required, it is usually either Christianity or Islam.

Western medicine have also affected traditional beliefs and practices. Orthodox medicine stresses the germ theory (pathology) of dieseases which rejects the traditional emphasis on spiritual forces due to the machinations of evil forces. The success of western medicine in dealing with tropical deseases has seriously undermined traditional medicine. The Western backed health care delivery system with its emphasis on curative and preventive medicine has led to a new hope and sucurity of life and this has automatically weakned the belief in and the fear of evil forces like witchcraft, magic and sorcery to cause sickness. The medicine man and the diviner have also lost some of thier respect in the bargain.

Foreign religions (espcially Christianity and Islam), acting as social forces, have played no small role in de-emphasising the signiface of the traditional Religion. Many converts to these religions have been indoctrinated against the Traditional Religion which is derogatorily designated as paganism, idolatry, heathenism and fetishism, and kafiri in Islam. In contrast to the traditional Religion which has no propaganda machinery with which to fight back and regain her lost adherents, Christianity and Islam have between them adequate and effective propaganda machinery with which to crucify the traditional faith and propaganda their beliefs. In addition to thier own national newspapers and magazines like the Catholic Standard, the Challenge and the Watch Tower and other religious tracts, these foreing religions control and use the mass media to promote the liquidation of the Traditional Religion. Occasional festival marking important landmarks in the lives of the founders of these faiths such as Eastern and Christmas for Christians and /d-E/Fitri and Id-El-Kabir for Muslims become national events and public holidays. Random visits by thier religious leaders such as the Pope and the Archbishop of Canterbury raise the dignity and the moral of the members to the detriment of the Traditional Religion.

In the midst of all these dangers and threats, many faithful adherents of the Traditional Religion are dying out, with very few people willing to take thier place. This is especially the case with the religious leaders. People are reluctant to come forward and be trained as priests, medicine men and diviners.

Thus the Traditional Religion is threatened by urbanization, industrialization, education, Western medicine, foreign religions and shortage of adherents.

\section{Conclusion}

This paper examines Western Education, religion and its functions, Yoruba concept of God, religion 
and morality, religion and social behaviour, then the effect of Western Education on Yoruba religious beliefs. Traditional religion are dying out with few people willing to take their place. If care is not taken the good cultural, moral and social values will fade away among the Yoruba people.

\section{Refrences}

Muhammad G.M Abuta (2011): N Education for Morality;A Panacea for Rebranding the Nigerian Society. Nigerian J ournal of Sociology of Education Vol. V. No 1

Fafunwa B.A (2004) History of Education in Nigeria; Ibadan NPS Educational Publisher Itd.

Federal Republic of Nigeria (2004): National Policy on Education, Lagos, Federal Ministry of Education.

J oseph S. Gbenda (2006) African Religion and Christanity in a changing world: A comparative approach, Nsukka,Chuka Educational Publishers, Nigeria.

T.N.O. Quarcoopome (1987) West African Traditional Religion Ibadan, African Universities Press Nigeria. 